\title{
ブルーム・ドンブラウン両文庫
}

佐藤林平

\section{1 横浜開港瓷料领}

この凟料館は1981年 6 月開館した。横浜市史編集の過程で収集された資料をもとにして, 横浜の開港期を中心として, 関東大震災頃に至るまでの横浜烕係凟料を多く収葴している。 この横浜開港資料馆（以下，資料館と略す。）のもつ意味については同館のガイドブック 「たますく」第 1 号及び第 2 号, 各特別展示およびそのパンフレット、資料館ニュース 「開港のひろば」各号, 就中, 1983-84の「資料にみる横浜の歴史」展とそのパンフレッ ト、資料馆がてれまでに企画した啸演会等から充分わかる通りであるが、筆者としてはと くに次の点を強調しておきたい。つまりての資料館の活動が横浜地方の歴史資料の地味で はあるが精密な研究を基碳としており，その上に立って一見華やかな，外国人，外国に関 する資料収集および所蔵が行われているという点である。この認識の上に立っててそ，資 料馆所葴の資料の充分な利用が可能になるのである。

\section{2 资料馆と笪者}

資料館との出会いは，幕末に来日したドイッ人画家ウィルヘルム・ハイネに威する資料， およびてれに関連してぺリー隊およびオイレンブルク東洋遠征政隊の資料をしらべるて とからはじまった。今では以上の資料以外に整末の怪ドイッ人シュネルに関する凅料を漁 るてとが多くなっている。ての過程で, 重要資料がブルーム文庫およびドン・フラウン文 庫に所蔵されているてとを知り，との二つの文庫に対する興味をそそられるようになった のである。

\section{3 プルーム文店}

(1) ポール・C・プルーム伝 ${ }^{(1)}$ 


$$
\text { 英学史研究第17年 }
$$

1898. 3. 31 横浜山手居留地に生れる。父アンリ・ブルームはアルザス地方出身 の猶太系フランス人, 1878年来日。輸出入業にたずさわる。母 Rose Isaacs は米人で横浜でアイザックス商会を経営するおぢを訪ずね て来日した。二人の結婚は1894年でろ。 ポールはセント・ジョセフ・カレッジで初等教育を受ける。

1912 ブルーム一家鯧国。ポールはスイスおよびパリ近郊で中等教育を受 ける。

1914

一家渡米。居を N.Y. に定める。ポールはコロンビア大.エール 大に学ぶ。第一次世界大戦に志願従軍。戦後エール大に戻る。卒業 後, 父の寈産を相続し, 南アメリカ, アフリカ, 東南アジア等各地 を旅行し，又际筆生活すする。このころより鲁籍の収集もはじめる。 1930代 アメリカとヨーロッパに居住。第 2 次大戦前数年はパリ郊外に住む。 ドイッ軍侵攻とともにアメリカへのがれる。

N.Y. に戻りコロンピア大学日本語科に在籍, その後米海外戦略局に 入り, 北イタリアの独軍降服工作や日本の降伏工作(スイスで)にる従事。

戦 後 米国務省睵貝として来日。1958以降は民間人として滞日。1952再建 された日本アジア協会の役員にえらばれる。

1978 蔵春他のコレクションを開港資料館へ意渡および奇䁬して㷌米。 N. Y.市に住む。

1981. 6 開港資料館開館式に出席するため来日。 1981. 8. 16 N.Y.のマウント・サイナイ病院で死去。（㹟心症）

1978. 5. 10 付の毎日新閒に徳岡孝夫氏 (後出)がフルルームについての思い出を語っている。

(2) プルーム文疰の概要（日本成係洋書のみについて）

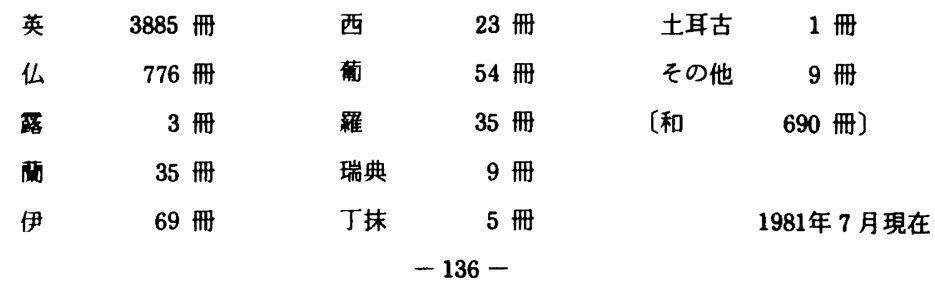




$$
\text { プルーム・ドンフラウン両文皇 }
$$

たらしこの数は必ずしあ辟密とはいえない。たとえば第 1 巻第 2 巻を別々に，または一 緒にして一冊と、いったように計算することがあるからである。两は主として出島関係。 伊西葡羅は主にイエズス会関係。（プルームはラテン語をよめた。）伯来語は英語の中に， 朝鮮語はその他の中に数えられる。

(3) ブルーム文庫の目録作成について。 「ブルーム・コレクション書籍目録」

第 1 巻（英語） A-L（1982．3．31刊）

第 2 巻（英語） - Z;（仏語）（1983，3，31刊）

第 3 巻（独・菏その他）（末刊）

(4) ブルーム文庫寄䁬

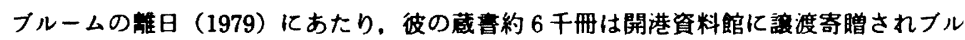
一ムコレクションとなったが, 更に1981年, 米国在住の同比の过族グレシン弁護士が横浜 市に対し、フルームが離日後さらに収集した日本関係資料 217 点（古地図、春籍、錦絵, 銅版画等）を資料館に寄撯曾したい旨申出がなされ、その通りになった。したがって現在資 料馆の「ブルーム・コレクション」総点数は約6500点となっている。

(5) フルームに寄䁬されたもの

フルーム文庫中,カード®（いろいろな分野に亘っている）のものは大体ブルームに奇 贈されたものであって，その中には献呈の辞のあるものもある。たとえばアレン・ダレス からのものはそうである。またブルーム文庫には Keene, Kerr, (いずれる後出) 両氏よ り寄兽されたるのが多い。また日本アジア協会成西支部を名乗っていた William Hawley Frank 氏からのあのあある。文庫にはアラビア語, ヘブライ語（いずれもゼロコピー） のものが含まれている。

(6) ブルームの交友関係

フルーム・コレクション帣籍目録第 1 巻の巻末に，彼の友人がブルームに関する憶い出 をかいているが,これも彼についてのすぐれた凟料である。

Donald Keene : Remembrances of Paul Blum (ポール・ブルームの情熱) 
英学史研究第17每

George. H. Kerr : Paul Blum; Collector of Books-Collector of Friends (41年の友情)

徳岡孝夫：「プルームさんと昔の横浜」

成松孝安：「ブルーム氏の三つの速産」

てのうちキーン教授（1922-）については,いまさらのべることはない。

ジョーシ・H・ケア氏は, 1940年でろ彼が東京の学校で 5 年間をすでした後大学院に入 るため, ニューヨークに戻り,てのコロンビア大学に在籍するに至ったブルームと知り合 つた。現在は60代の半ばに達しているようである。日本では大学まで出ている。第二次大 戦中および戦後、米海軍および国務省で, 台湾, 沖縄問題のエキスパートとして活墔した。 台湾および神縄に関する著鲁がある。（そのいくつかはフルルム文庫に入っている。）見 在はハワイに在住。

徳岡孝夫氏（1930－）は京都大学を出てからシュラキーズ大学新聞学科を修了し ている。毎日新聞社編集委員。国際人として足址をのてし, 多くの著訳書がある。資料館 の委啒で, 米本土で資料収集にあたっている。

成松孝安氏（1925生）はブルームのハウスキーパーを長らくつとめた。スパゲティ専門 店「壁の穴」の経営にあたっている。フルームの地図および錦絵の収集に協力した。成松 氏が日本語のできないブルームの日本に関する著訳にどの程度協力したかという問題につ いて晩年は少くともそういう協力はなかったと思われる。この時期は，ある女性がブルー 么の世話をしたのであり,ての女性が手伝ったというととはおり得る。

フルームに松本清張の「点と線」の糊訳かるが、この糊訳に誰が協力したかはかから なかった。るちろん成松氏だともいえない。

ちなみに, 成松氏は度応義塾大学の通信教育部（経済学部）に1948-49に在籍したこと がある。 ${ }^{(6)}$

(7) フルルームの著訳について ${ }^{(7)}$

ブルームの著書と訳書

著書・編書

モリス。ブルーム共編「アジア協会紀要索引」東京 アジア協会紀要 1958

I. I. Morris \& P. C, Blum, Comprehensive Index to the Transactions of 


$$
\text { ブルーム・ドンブラウン両文 }
$$

the Asiatic Society of Japan

「品川寺の鐿」東京 ジャパン・クォーターリー1959年第 2 号

P. C. Blum, The Bell at Shinagawa-ji, Japan Quarterly

「1872年の横浜ーアジア協会創設のととども一」東京 1963

P. C. Blum, Yokohama in 1872: a Rambling Account of the Community in Which the Asiatic Society of Japan Was Founded*

「中浜万次郎の二つの世界」東京 在日米国商業会議所月報1968年10月号

P. C. Blum, The Two Worlds of Nakahama Manjiro, The Journal of the American Chamber of Commerce in Japan

訳書

ヘロルト「「仏陀の生涯」ニューヨーク 1927

A. F. Herold, The Life of Buddha, tr. by P. C. Blum

ユーシェ「現代フランス桧画集」ニューヨーク 1939

R. Huyche, French Painting : The Contemporaries, tr. by P. C. Blum

Kondo Ichitaro「東洲斎写楽」東京 1955

I. Kondo, Toshusai Sharaku, tr. P. C. Blum

松本清張「点と腺」東京 1970

S. Matsumoto, Points and Lines, tr. by P. C. Blum

「ムニクウ神父の幕末日記」東京 アジア協会紀要 1976

P. C. Blum, tr: "Father Mounicou's Bakumatsu Diary," The Transactions of the Asiatic Society of Japan

ペスーンマサブォー「日本列島」

J. Pezeu-Massabuau, The Japanese Islands, tr. by P. C. Blum

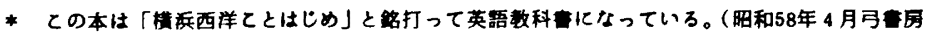
刊。長谷川・生野圂注)

とてろで著訳春のうちいくつかについて少しのへておきたい。

「品川寺の籍」The Bell at Shinagawa-ji. 乙れは Through the Eastern Window の一つ。3 頁弱の短いものである。

「中浜万次郎の二つの世界」The Two World of Nakahama Manjiro 10頁 
英学史研究 第17年

はど。これには1852年に出版された版画がいくつか载っている。「無人岶にてトラクロ

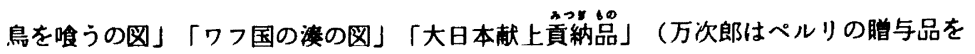
あずかっていた。)

「ムニクウ神父の策末日記」Father Mounicou's Bakumatsu Diary これはフ ルームの一番の労作といってよいであろう。掌末日本についてはフランス側の凅料が比 较的尠いてとからあ価值が多い。フルームがてれにとりくむにあたって英語仏語满語独 乙語の資料にひろくおたったてとは，巻末の Bibliography に記載されている50余点 の瓷料から判る。（ムニクウ神父については，「横浜フランス物語」(昭54:富田仁著） 他多くの日本仏学の春隹記載されている。)

4 ドン・フラゥン文店

(1) ドン・ブラゥン伝 (Donald Beckman Brown 通称ドン・ブラウン)

1905. 6. 24 オ八イオ州クリーウランド生。

1929 ピッッパーグ大学卒業。

$1933-36$ 頃 Japan Advertiser 紙 rewrite editor。

1939頃同社の executive editor。

〔1940. 10. 10 Japan Advertiser 紙, Japan Times に合併。後者は Japan Times and Advertiser と改名。乙の合併後, トン・ブラゥンは 退社, 㷌米していろ)

太平洋戦争中 ニューヨークで国務省勒務。対日情報戦略の業務に揞わる。

戦後

GHG の GIE（情報教育局）におりる，情報媒体関係担当官とし て来日。（米将校として）

(以後死ぬまで東京に在住した)

担当官の仕事のひとつに, 輸入映画の監查と, 映画会社への給の 管理があった。日本再軍備促進のため反戦映画をシャットアウトし たり,アラビアンナイトを倫理上から不合格にしたという。

1947〜 アジア協会の戦後最初の委員会のメンバーに選出。以後死去するま でその任にあった。

1950〜 アジア協会の出版委員会・委員長, 以後死ぬまで, 事実上紀要の編 集長をつとめた。編集にあたっては, 完全主義者で最高の水準を要 
ブルーム・ドンブラウン文积

求したので定期的発行がおくれた。

1954〜64 アジア協会の委員会副委貝長。

1960代初期〜 国務省勤務（?）功引退したのち, アジア協会の活動に専念, 19 -20世紀の外国人の手による日本関係の籍・新聞・雑誌の収集や, 自分の藏春の整理にもいそしんだ。

当時ウィザの関係上 Blakemore 氏（後出）の事務所に週 2 日出 勤していた。

1980

名古屋の友人宅*に滞在中入院。5月17日死去。肺程（?）

* アサカワ医院

(以上 Don Brown 追倬文に拋る]

(2) トン・ブラウン文庫が資料館におさまった経過。

横浜市粉務局発行の資料（昭56.12.24）には次のようにかかれている。

「てれら資料の一部は，競売にかけられ隻散するほか，大部分はオーストラリアのあ ろ公立図寒館に納入されるところであったが、横浜市では，こうした貫重な横浜関係資料 の散逸や海外流出を防ぐため，故人の財産管理人代理者のブレークモア氏とねばり強く交 涉を重ね，横浜市民にとって極めて重要な資料群であることを説明し，米国に在住する速 族の方々の同意を得て、秋口には，横浜開港資料馆に収蔵し，末永く保存することで両者 の合意が成立しました。

このたひ，同資料が納入され，生前，友人示係仁おった故ポール・C・ブルーム氏とド ナルト゚・B・ブラゥン氏の資料が，横浜開港資料館の 3 階収葴庫で再会し，仲よく同居す ろととになりました。….」

(3) ドナルド・B・ブラゥンコレクションの貫重資料 ${ }^{(8)}$

1.「ジャパン・ヘラルド」

横浜居留地で最初に発行された英字新聞で，文久 2（1862）年〜悬応元（1865）年ま でのあのが,ほほ完全にそろっている。

2.「ジャパン・パンチ」

横浜居留地でワーグマンが発行した風刺雑誌で, 慶応 2 （1866）年〜明治19（1886）

年までのあのが, 一部欠本はあるもののよくそろっている。 


$$
\text { 英学史研究第17昌 }
$$

3.「ジャパン・エバンゲリスト」

横浜で発行されたキリスト教ミッション雑誌で、てれは全てそろっている。

4.「ジャパン・ウィクリーメール」

横浜居留地で発行された英字新聞で, 明治11（1878）年〜同44（1911）年までのあの が,とびとびではあるがそろえてある。

5.「ファー・イースト」

横浜居留地でブラックが発行した写真はりつけの新聞で。これあかなりそろえておる。

6.「ジャパン・クロニクル」

神戸居留地で発行された英字新聞であるが，てれについても明治37 (1904) 年〜昭和 15 (1940) 年までのものがよく残されている。

(4) ドン・ブラウンの交友関係

Paul C. Blum 氏

島内敏郎氏（1909- ）佐賀県出身。加州オクシデンタル大卒。外交官。在米勤務が 長く、ノルウェー大使にもなっている。また退官後ボーイスカウト国際コミッショナ 一になっている。

Dr. Blakemore (トマス・エル・ブレイクモア) 法律家。ドン・ブラウンが Japan Advertiser の主筆であった時代からの知己であり, 氏の妻になった Francis はド ン・ブラゥンの下で倬いたことがあるという。

(5) ドン・ブラウンの著作

Libraries with T. A. S. J. Holdings 東京 （日本アジア協会紀要の1958の索引 号に所収) 英国、米国, カナダ、ニュージーランドの日本アジア協会紀要所葴につい てのべている。

On the Significance of the Asiatic Society of Japan 東京 1965 日本アシ ア協会紀要の索引（1872-1922）の序文。乙れは日本英学史研究には必須なすので内 容は 1. 欧米における日本研究と設立された諸協会。(日本アジア協会成立以前) 2. 日 本アジア協会の成立事情とその活動。協会に貢献せる外国人。とくに宣教師, 外交官。 3. 日本アジア協会に関与せる日本人。4. 日本アジア協会とドイッ文化協会とのかか わり,などについて手際よくまとめたものである。 


$$
\text { ブルーム・ドンブラウン文田 }
$$

(6)資料館「日本アジア劦会紀要」の所蔵について。

ブルーム文庫, ドン・ブラゥン文庫両方にある。最近のあのまで所蔵されている。後者 の方がよくそろっている。

\section{あとかき}

本稿は研究発表とはいえない。策者の研究上多大の便宜をはかって下さっている，横浜 開港資料館の重要な二つの文庫の紹介と、それらの文庫に名前を冠した二人の米人日本研 究家、春籍収集家、ブルーム、ドン・ブラウン両氏についてしらべた結果を活字にしたも のにすぎない。両氏とも独身を通した点は共通であったが，ブルーム氏が資料館開館当時 元気であって来館され、日本英学史学会会長池田折郎氏と钦談されたと同っているし，遭 族もかなり残って居られるに対し，ドン・ブラゥン氏は亡くなって年数も経ており，資料 館との直接交涉むなく，造族とも直接連絡がとれなかったという連いがある。なお両文庫 が資料館に所葴されるに至った手続きについて更にのべるなら゙，次のととをつけ加えて おかねばならないであろう。

ブルーム文庫——部は睛入であり, 他は兽与。その時々の睡入契約書はあるが, 䁬与 目録はない。現在文庫の春籍目録が作製されつつおる。

ドン・ブラゥン文庫—4850万で睛入。管勖人と交渉して折り合ったわりである。目

録は Auction の目録がある。この目録は度応義塾大学の学生がその作製に大いに寄 与したとうかがっている。

ブルーム氏にもドン・ブラウン氏にあ，筆者はその生前にお目にかかれるという幸運 を有していないが, 現在その学恩を大いに受けているわけである。こてに感謝して両氏の 冥福を新りたい。日本アジア協会はかつて度度冢整におかれたてとがあるが，現在青山の 草月会馆内でドィッ文化協会に同居しているのも感慨深いてとである。

最後に本稿をかく際，非常にお世話になった横浜資料館の伊藤久子館員に対し感謝をさ さげたい。 


\section{英学史研究第17号}

〔注〕

（1）現在ニューヨーク在住のジー゙ピアニストRobert Greene 氏（フルームの促㚴姝の子息） が，彼の层眍を執䨣中であるという。

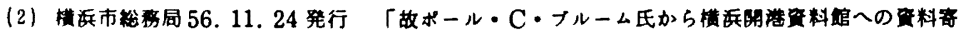
につい」

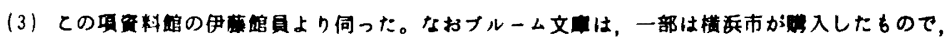

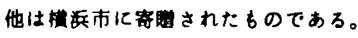

(4) 以上同氏の著書のフラップ等に站る。

（5）「胃代日本執等者典」1978 日外アソシェーツ、に片る。

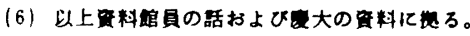

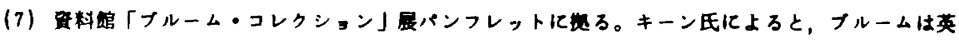

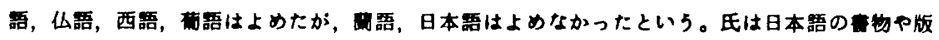
画の梧通をブルームのため訳したと㶾っている。

(8) 料䗆の料にる。

(9)「人事興信録昭58年版」に㢸ろ。

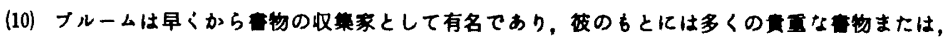

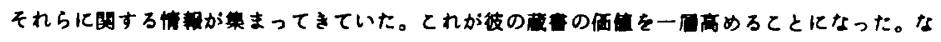

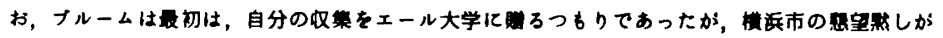
たく、とれらは料领におさまるととになったのである。

〔付衭：本稿は1983年 4 月の日本英学史学会例会で行った口頭発表をもとにしている〕 